\title{
Efficacy and safety of the single-capsule combination of fluticasone/formoterol in patients with persistent asthma: a non-inferiority trial*
}

\author{
Eficácia e segurança da associação fluticasona/formoterol em cápsula \\ única em pacientes com asma persistente: estudo de não inferioridade
}

\author{
Marti Antilla, Fábio Castro, Álvaro Cruz, Adalberto Rubin, Nelson Rosário, Rafael Stelmach
}

\begin{abstract}
Objective: Fluticasone and formoterol are effective in the treatment of asthma. When a corticosteroid alone fails to control asthma, combination therapy is the treatment of choice. The objective of this study was to compare the efficacy and safety of formulations containing budesonide/formoterol (BUD/FOR), fluticasone alone (FLU), and the single-capsule combination of fluticasone/formoterol (FLU/FOR) on lung function in patients with mildto-moderate persistent asthma. Methods: This was a randomized, multicenter, open phase 111 trial conducted in Brazil. The primary efficacy analysis was the assessment of non-inferiority between FLU/FOR and BUD/FOR combinations regarding FEV ${ }_{1}$ (in $\mathrm{L}$ ) at the final visit. The secondary analyses were PEF, level of asthma control, serum cortisol levels, frequency of adverse events, adherence to treatment, and appropriate inhaler use. Results: We randomized 243 patients to three groups: FLU/FOR $(n=79)$, BUD/FOR $(n=83)$, and FLU $(n=81)$. ln terms of the mean FEV after 12 weeks of treatment, the difference between the FLU/FOR and BUD/FOR groups was $0.22 \mathrm{~L}(95 \% \mathrm{Cl}:-0.06$ to 0.49 ), whereas the difference between the FLU/FOR and FLU groups was $0.26 \mathrm{~L}$ (95\% $\mathrm{Cl}:-0.002$ to 0.52$)$. Non-inferiority was demonstrated by the difference between the lower limits of the two 95\% Cls (-0.06 vs. -0.002$)$. The level of asthma control and PEF were significantly greater in the FLU/FOR and BUD/FOR groups than in the FLU group. There were no significant differences among the groups regarding patient adherence, patient inhaler use, or safety profile of the formulations. Conclusions: The single-capsule combination of FLU/FOR showed non-inferiority to the BUD/FOR and FLU formulations regarding efficacy and safety, making it a new treatment option for persistent asthma.
\end{abstract}

Keywords: Asthma; Steroids; Bronchodilator agents; Administration, inhalation.

(ClinicalTrials.gov Identifier:NCT01202084 [http://www.clinicaltrials.gov/])

\section{Resumo}

Objetivo: A fluticasona e o formoterol são efetivos no tratamento da asma. A terapia combinada é o tratamento de escolha quando o corticosteroide isolado não controla a asma. 0 objetivo deste estudo foi comparar a eficácia e segurança de formulações contendo budesonida/formoterol (BUD/FOR), fluticasona (FLU) e fluticasona/ formoterol (FLU/FOR) em cápsula única sobre a função pulmonar em pacientes com asma persistente leve e moderada. Métodos: Estudo de fase 111 multicêntrico brasileiro, aleatorizado e aberto. A análise primária de eficácia foi a avaliação de não inferioridade da combinação FLU/FOR perante a combinação BUD/FOR em relação ao $\mathrm{VEF}_{1}(\mathrm{em} \mathrm{L})$ na visita final. As análises secundárias foram PFE, nível de controle da asma, nível de cortisol sérico, frequência de eventos adversos, aderência ao tratamento e uso adequado do inalador. Resultados: Foram randomizados 243 pacientes nos grupos FLU/FOR $(n=79)$, BUD/FOR $(n=83)$ e FLU $(n=81)$. Após 12 semanas de tratamento, a média da diferença do $\mathrm{VEF}_{1}$ foi de $0,22 \mathrm{~L}(1 \mathrm{C} 95 \%$ : $-0,06$ a 0,49) entre os grupos FLU/FOR e BUD/FOR e de 0,26 L (IC95\%: -0,002 a 0,52) entre os grupos FLU/FOR e FLU. A não inferioridade ficou demonstrada pela diferença de limite inferior do 1C95\% (-0,06 vs. -0,002). 0 nível de controle da asma e o PFE foram significativamente maiores nos grupos FLU/FOR e BUD/FOR em comparação com o grupo FLU. Não houve diferenças significativas em relação a adesão, uso do inalador e perfil de segurança entre os grupos. Conclusões: A combinação FLU/FOR em cápsula única apresentou eficácia e segurança não inferior às formulações BUD/FOR e FLU e representa uma nova opção de tratamento para asma persistente.

Descritores: Asma; Esteroides; Broncodilatadores; Administração por inalação.

(ClinicalTrials.gov Identifier:NCT01202084 [http://www.clinicaltrials.gov/])

*Study carried out at the Consultoria Médica em Pesquisa Clínica - CMPC, Medical Consulting Center for Clinical Research Sorocaba, Brazil; the Advanced Medicine Institute, São Paulo, Brazil; the Programa para o Controle da Asma na Bahia - ProAR, Bahia State Asthma Control Program - Salvador, Brasil; the Santa Casa Sisters of Mercy Hospital Complex in Porto Alegre, Porto Alegre, Brasil; the Paraná State Clinical Research Institute, Curitiba, Brazil; and the Stelmach Clinical Research Center, São Paulo, Brazil. Correspondence to: Rafael Stelmach. Rua Vergueiro, 1353, Conjunto 1307-Norte, CEP 04101-000, São Paulo, SP, Brasil.

Tel. 5511 2365-5357. E-mail: pesquisa@pesquisastelmach.com.br

Financial support: This study received financial support from Eurofarma Laboratórios S/A.

Submitted: 9 June 2014. Accepted, after review: 4 August 2014. 


\section{Introduction}

Asthma is currently one of the most common chronic diseases in the general population. ${ }^{(1)}$ It is estimated that there are approximately 300 million asthma patients worldwide, 20 million of whom are in Brazil. ${ }^{(2)}$ The central pathophysiological feature of asthma is airway inflammation, which is present in patients with mild asthma and even in asymptomatic patients. ${ }^{(3)}$ The primary focus of treatment is on reducing inflammation.

The primary objective of asthma management is to achieve and maintain disease control. ${ }^{(4)}$ The drugs and doses used for maintenance therapy should be changed according to the level of asthma control. ${ }^{(1)}$ The ideal treatment for asthma patients is one that controls and stabilizes the disease with the lowest possible dose of medication. Inhaled corticosteroids (ICs) are the most effective anti-inflammatory drugs for the treatment of patients with weekly, daily, or continuous symptoms. ${ }^{(5)}$

The 1Cs that are currently available (beclomethasone, budesonide, ciclesonide, fluticasone, and mometasone) differ in terms of their potency and bioavailability; however, studies have shown that the differences have no clinical relevance. ${ }^{(6)}$ Formoterol and salmeterol are long-acting $\beta_{2}$ agonists (LABAs) and should not be used as monotherapy, because they have no effect on asthmatic inflammation. They are much more effective when administered in combination with an 1 . $^{(1)}$

When an average dose of an $1 \mathrm{C}$ alone fails to control asthma, combination therapy is the treatment of choice. The addition of LABAs to the daily $\mathrm{IC}$ dose reduces daytime and nighttime symptoms, improves lung function, reduces the need for rescue medication, and reduces the number of exacerbations, ${ }^{(3,7)}$ as well as promoting clinical control in a larger number of patients, doing so more quickly and with lower $1 \mathrm{C}$ doses. ${ }^{\left({ }^{(8)}\right.}$

The greater efficacy of combination therapy led to the development of inhalers that release fixed doses of $1 \mathrm{Cs}$ and LABAs simultaneously. Treatment with $1 \mathrm{Cs}$ and LABAs administered together is as effective as is treatment with 1Cs and LABAs administered separately. ${ }^{\left({ }^{(9)}\right.}$ The use of a single inhaler containing fixed drug combinations is more convenient for patients and can therefore increase treatment adherence ${ }^{(10)}$ and guarantee that the LABA is always administered together with the $1 C$.
In addition to the drug itself, adherence to treatment, the type of inhaler, and the technique used in order to administer the drug are equally important for successful treatment. Poor adherence to treatment is common in asthma patients, treatment adherence rates ranging from 16\% to $50 \% .^{(11)}$ The correct use of inhalers allows selective treatment of the lungs and reduces systemic adverse effects. ${ }^{(12,13)}$ The effectiveness of inhaled medications depends not only on the formulation and type of inhaler used but also on the ability of patients to use proper inhalation techniques. ${ }^{(14)}$

In a study comparing the formoterol/ budesonide combination with the salmeterol/ fluticasone combination, no statistically significant differences were found between the two combinations regarding the frequency of asthma exacerbations requiring emergency medical care, hospitalization, and oral corticosteroid use. ${ }^{(15)}$ These findings, however, can obscure individual differences among the components. One group of authors concluded that, when administered at half the dose of budesonide, fluticasone had a greater effect on lung function at all doses used, in all age groups studied, and for all types of devices used. ${ }^{(16)}$ Formoterol and salmeterol have been associated with different outcomes. The use of formoterol has been associated with significantly improved lung function, reduced need for rescue medication, and a greater proportion of symptom-free days when compared with the use of salmeterol. ${ }^{(17)}$

The formoterol/fluticasone combination is currently unavailable for purchase in Brazil. The experimental product containing the formoterol/ fluticasone combination might be a new treatment option for asthma. The objective of the present study was to compare the efficacy and safety of budesonide/formoterol (two separate capsules), fluticasone alone, and the new, single-capsule combination of fluticasone/formoterol, all of which were delivered by dry powder inhalers (DPIs). Secondary objectives included correct inhaler use, preferred inhaler, and adherence to treatment.

\section{Methods}

This was a randomized, open-label phase 111 study conducted at six research centers in Brazil. The study population consisted of patients who met the following inclusion criteria: being 12 
years of age or older; having been diagnosed with mild-to-moderate persistent asthma, ${ }^{(1)}$ with symptoms for at least 6 months; having been clinically stable for at least 1 month; having an Asthma Control Questionnaire 7 (ACQ-7) score $\leq 3^{(18)}$; currently using an $1 C$ equivalent to up to $1,000 \mu \mathrm{g}$ of beclomethasone dipropionate, either in isolation or in combination with a LABA; and presenting with a pre-bronchodilator $\mathrm{FEV}_{1}>40 \%$ of the predicted value. The exclusion criteria were as follows: having required hospitalization for asthma or having used oral or parenteral corticosteroids in the 3 months preceding the study; having been an active smoker in the past 3 months; presenting with severe comorbidities; having participated in other clinical studies in the past 12 months; being pregnant or lactating; and receiving chronic treatment with beta blockers. All participants gave written informed consent. The study was conducted in accordance with Good Clinical Practice guidelines and the Declaration of Helsinki. ${ }^{(19)}$

In order to increase group homogeneity and prior to randomization, patients were stratified by research center and baseline pre-bronchodilator FEV $_{1}: 40-70 \%$ of predicted vs. $\geq 70 \%$ of predicted. By means of a centralized electronic system, patients were randomly allocated (at a 1:1:1 ratio) to one of three groups (treatment arms): the BUD/FOR group, comprising patients receiving a combination of formoterol $(12 \mu \mathrm{g})$ and budesonide $(400 \mu \mathrm{g})$ delivered via an Aerolizer-type DPI with two separate capsules (Foraseq ${ }^{\circledR}$; Novartis Biociências S.A., São Paulo, Brazil); the FLU group, comprising patients receiving fluticasone $(500 \mu \mathrm{g})$ delivered via a Diskus ${ }^{\circledR}$-type multipledose DPI (Flixotide ${ }^{\star}$; GlaxoSmithKline Brazil, Rio de Janeiro, Brazil); and the FLU/FOR group, comprising patients receiving the new, singlecapsule combination of $12 \mu \mathrm{g}$ of formoterol and $250 \mu \mathrm{g}$ of fluticasone propionate (Eurofarma, São Paulo, Brazil) delivered via a CDM-Haler DPI (Emphasys Industrial, Boituva, Brazil). All inhaled drug therapies were administered twice a day $(12 / 12 \mathrm{~h})$.

Patients were evaluated at the initial visit-the screening visit (SV)-and were randomized within $15 \pm 5$ days after the SV-the randomization visit (RV)-being re-evaluated at visit 1 (V1), visit 2 (V2), and the final visit (FV), 4 weeks apart. Between the SV and the RV, patients continued to use their medications, underwent measurement of cortisol levels, received a diary for PEF measurements, and, when appropriate, underwent a pregnancy test. The follow-up period was at least 12 weeks. The primary outcome measure of the present study was FEV (in L) at the FV. Secondary outcome measures included serial PEF measurements, the level of asthma control, correct inhaler use, the frequency of adverse events, and the variation in serum cortisol levels throughout the study period. At all visits after the RV, adherence to the study medication was assessed by counting the capsules/doses used.

Spirometry was performed at all visits, in accordance with asthma management strategies. ${ }^{(2,20)}$ Over the course of treatment, PEF was measured in the morning and in the evening, the best of 3 measurements being recorded by patients in their diaries and subsequently evaluated by the principal investigator. ${ }^{(21)}$

Asthma control was assessed by ACQ-7 scores ${ }^{(18)}$ at the SV, at V1, at V2, and at the FV. ACQ-7 consists of seven questions regarding asthma symptom control, rescue medication use, and FEV $_{1} \%$. A score $\leq 1.57$ (total score, 6 points) indicates controlled asthma. Over the course of the study, clinical assessment of asthma control was performed by the principal investigator in accordance with the Global Initiative for Asthma criteria (i.e., uncontrolled, partially controlled, and controlled asthma). ${ }^{(1)}$

Between the RV and the FV, correct inhaler use was scored on an eight-point scale. During V1 and the FV, patients answered categorical questions (yes/no questions) and one continuous variable question (graded from zero to 10) regarding the acceptability of the three inhalers and patient preference for a particular device. Serum cortisol levels were determined at the beginning and end of the study. Adverse events were recorded by the principal investigator at $\mathrm{V} 1$, at $\mathrm{V} 2$, and at the FV.

In order to calculate the sample size, we considered that the primary outcome measure mean FEV (in L) after 12 weeks of treatment would be at least equal in all three groups in the present study. We considered a non-inferiority margin of 7.5\%, which was assessed in the primary efficacy analysis comparing the FLU/FOR and BUD/FOR groups in terms of the mean FEV ${ }_{1}$ after 12 weeks of treatment. On the basis of literature data, we considered a mean FEV of $2.81 \mathrm{~L}$, with an estimated standard deviation of 0.43 
L. Considering a one-tailed type 1 error of $2.5 \%$ and a statistical power of $80 \%$ for detecting a maximum difference of 7.5\% among the groups (non-inferiority limit), we estimated that 67 patients should be included in each treatment group. Assuming a 15\% loss to follow-up, we calculated that 243 patients (81 patients per group) were required.

Continuous variables with normal distribution were analyzed by mean and standard deviation, whereas those with non-normal distribution were analyzed by median and interquartile range. Categorical variables were described by relative frequencies. The Kolmogorov-Smirnov test was used in order to evaluate the pattern of distribution of the study variables. Continuous variables with normal distribution were compared by t-tests or ANOVA. Nonparametric tests were used for variables with non-normal distribution. The MannWhitney test was used for comparisons between two groups, whereas the Kruskal-Wallis test was used for comparisons among the three groups.

\section{Results}

A total of 273 patients were included in the present study, and 243 were randomized: 79 to the FLU/FOR group; 83 to the BUD/FOR group; and 81 to the FLU group. Of the 242 eligible patients who received treatment- 1 was excluded after randomization because of the use of beta blockers-all were included in the safety population, and 235 were included in the intent-to-treat (ITT) population for having at least one evaluation of any of the study outcomes. The demographic and clinical characteristics of the patients in the ITT population are shown in Table 1.

The per-protocol (PP) population consisted of 195 patients for whom there were FEV data $_{1}$ at the end of the study. As can be seen in Figure 1, 7 patients were not included in the ITT population (because they missed all visits after the SV), and 47 patients were not included in the PP population (because they had no evaluation of the primary outcome, because they were excluded for failing to meet the study criteria, or because of other significant deviations).

Regarding the primary outcome measure FEV after 12 weeks of treatment, the FLU/FOR, BUD/ FOR, and FLU groups were similar. In the FLU/ FOR, BUD/FOR, and FLU groups (ITT population), mean $\mathrm{FEV}_{1}$ values were $2.53 \pm 0.77 \mathrm{~L}, 2.50 \pm$
$0.87 \mathrm{~L}$, and $2.41 \pm 0.62 \mathrm{~L}$, respectively; at the FV, mean FEV , values were $2.72 \pm 0.81 \mathrm{~L}, 2.50 \pm$ $0.82 \mathrm{~L}$, and $2.45 \pm 0.73 \mathrm{~L}$, respectively. Figure 2 shows the descriptive statistics for $\mathrm{FEV}_{1}$ (in $\mathrm{L}$ and in $\%$ of predicted) throughout the study period in all three treatment groups. Over the course of treatment, there were significant differences among assessments $(p<0.001)$ but no significant differences among the groups. In terms of the mean $\mathrm{FEV}_{1}$ after 12 weeks of treatment (PP population), the difference between the FLU/ FOR and BUD/FOR groups was $0.22 \mathrm{~L}(95 \% \mathrm{Cl}$ : -0.06 to 0.48 ), whereas the difference between the FLU/FOR and FLU groups was $0.26 \mathrm{~L}(95 \% \mathrm{Cl}$ : -0.002 to 0.520 ). The primary efficacy analysis comparing the new, single-capsule combination of fluticasone/formoterol and the budesonide/ formoterol combination showed non-inferiority, given that the lower limit of the $95 \% \mathrm{Cl}$ for the difference between the two combinations in terms of the mean $\mathrm{FEV}_{1}$ at the FV $(-0.06)$ was greater than the pre-established non-inferiority margin $(7.5 \%$ of the FEV , obtained with the use of the budesonide/formoterol combination, i.e., $-0.18)$. The secondary efficacy analysis comparing the single-capsule combination of fluticasone/ formoterol and fluticasone alone also showed non-inferiority.

Our analysis of the PEF in the morning and in the evening showed no significant differences among the groups in relation to baseline values. However, when we analyzed the combination of morning and evening PEF values throughout the study, we found significant differences among the groups $(p=0.02)$. We also found that the visits had an effect on PEF ( $p<0.001)$ and that there were interactions between visits and groups ( $p=0.01)$. In the FLU/FOR, BUD/FOR, and FLU groups, combined PEF values at the end of the study (for the ITT population) were $382.1 \pm 118.4 \mathrm{~L} / \mathrm{s}, 364.9 \pm 115.2 \mathrm{~L} / \mathrm{s}$, and 324.3 $\pm 92.1 \mathrm{~L} / \mathrm{s}$, respectively. These results suggest that there was a gradual increase in overall PEF measurements throughout the study, especially in the FLU/FOR and BUD/FOR groups.

Figure 3 shows ACQ-7 scores per treatment group throughout the study (i.e., for the ITT population). There were statistically significant differences among treatments at $\mathrm{V} 1(\mathrm{p}<0.001)$ and at the FV $(p<0.05)$ but not at the RV or at V2. In the FLU/FOR, BUD/FOR, and FLU groups, mean ACQ-7 scores after 12 weeks of 


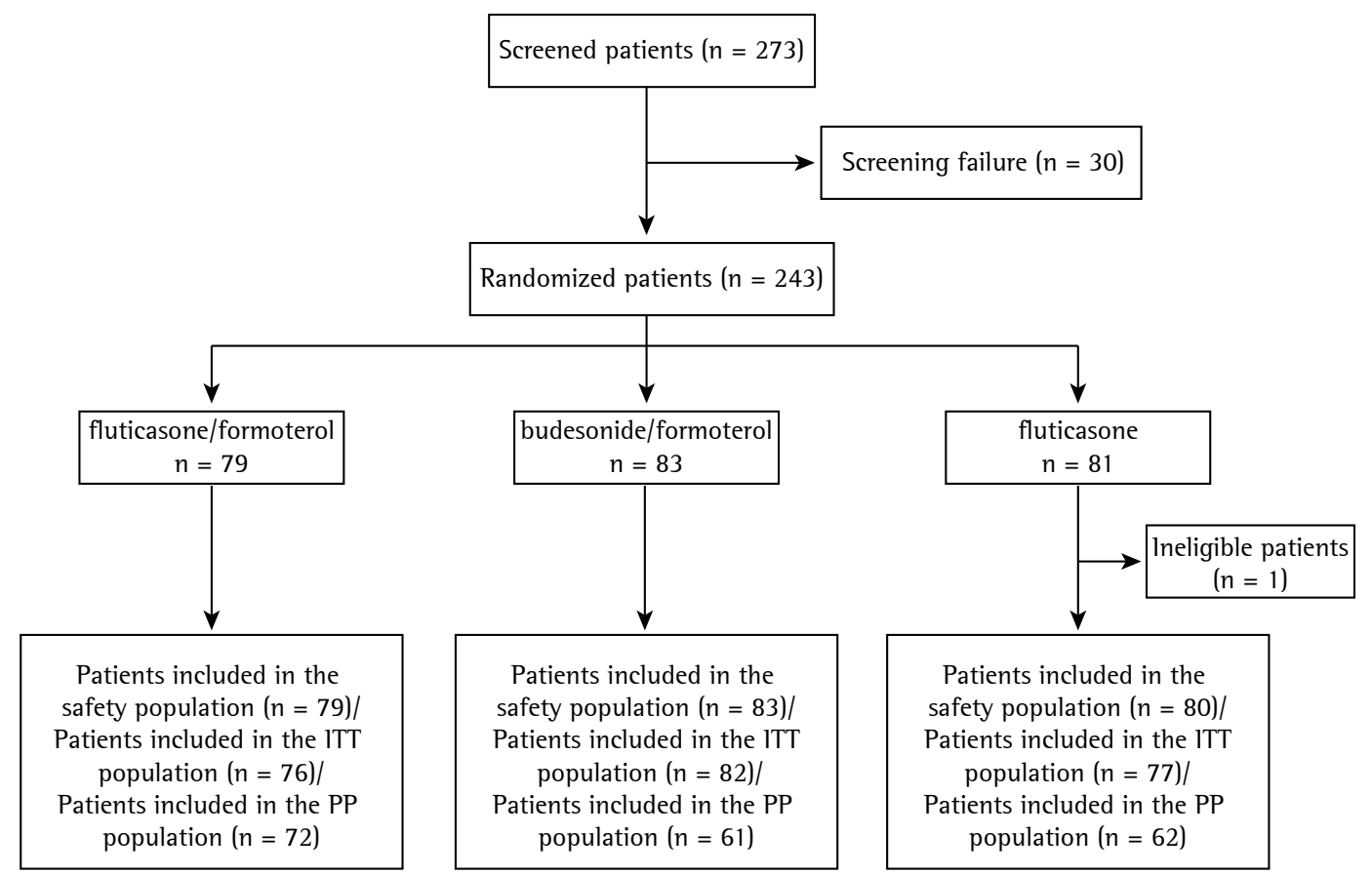

Figure 1 - Flowchart of patients in the per-protocol (PP), intent-to-treat (ITT), and safety populations.

Table 1 - Demographic and clinical characteristics of the intent-to-treat population of patients, distributed by treatment group $(\mathrm{n}=235) .{ }^{\mathrm{a}}$

\begin{tabular}{|c|c|c|c|}
\hline \multirow[t]{3}{*}{ Characteristic } & \multicolumn{3}{|c|}{ Groups } \\
\hline & Fluticasone/formoterol & Budesonide/formoterol & Fluticasone \\
\hline & $(n=76)$ & $(n=82)$ & $(\mathrm{n}=77)$ \\
\hline Age, years ${ }^{b}$ & $36.72 \pm 17.72$ & $40.82 \pm 16.88$ & $39.08 \pm 15.86$ \\
\hline \multicolumn{4}{|l|}{ Gender } \\
\hline Female & $49(64.5)$ & $55(67.1)$ & $61(79.2)$ \\
\hline Male & 27 (35.5) & $27(32.9)$ & $16(20.8)$ \\
\hline \multicolumn{4}{|l|}{ Race } \\
\hline White & $47(61.8)$ & $52(63.4)$ & $43(55.8)$ \\
\hline Black & $16(21.1)$ & $11(13.4)$ & $15(19.5)$ \\
\hline Mulatto & $13(17.1)$ & $19(23.2)$ & $19(24.7)$ \\
\hline $\mathrm{BMI},{ }^{\mathrm{b}} \mathrm{kg} / \mathrm{m}^{2}$ & $27.00 \pm 5.63$ & $27.37 \pm 5.65$ & $27.84 \pm 4.57$ \\
\hline \multicolumn{4}{|l|}{ Smoking status ${ }^{\mathrm{c}}$} \\
\hline Former smoker & $12(15.8)$ & $11(13.4)$ & $9(11.7)$ \\
\hline Never smoker & $64(84.2)$ & $71(86.6)$ & $68(88.3)$ \\
\hline \multicolumn{4}{|l|}{ Level of asthma control } \\
\hline Controlled & $43(59.7)$ & $38(62.3)$ & $44(71.0)$ \\
\hline Uncontrolled & $1(1.4)$ & $2(3.3)$ & $2(3.2)$ \\
\hline Partially controlled & $28(38.9)$ & $21(34.4)$ & $16(25.8)$ \\
\hline $\mathrm{FEV}_{1}, \mathrm{~L}^{\mathrm{b}}$ & $2.53 \pm 0.78$ & $2.53 \pm 0.89$ & $2.35 \pm 0.59$ \\
\hline $\mathrm{FEV}_{1}, \%$ of predicted ${ }^{\mathrm{b}}$ & $82.07 \pm 18.06$ & $81.44 \pm 17.24$ & $81.44 \pm 17.25$ \\
\hline
\end{tabular}

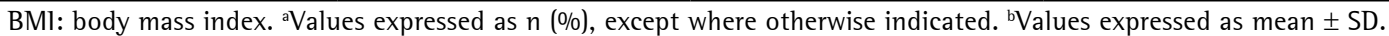
'Had been a smoker up until three months prior to study entry.

treatment were $0.71 \pm 0.7,0.93 \pm 0.07$, and $0.98 \pm 0.07$, respectively. Median ACQ-7 scores at the FV show that there were significant differences among the treatment groups ( $p<$ $0.05)$. These results of the interaction between groups and assessments suggest that although 



Figure 2 - Mean FEV, values in $\mathrm{L}$ (in A) and in \% of predicted (in B) in the fluticasone/formoterol (FLU/ FOR), fluticasone (FLU), and budesonide/formoterol (BUD/FOR) groups (intent-to-treat [ITT] population) at each visit. SV: screening visit; V1: visit 1; V2: visit 2; and FV: final visit.

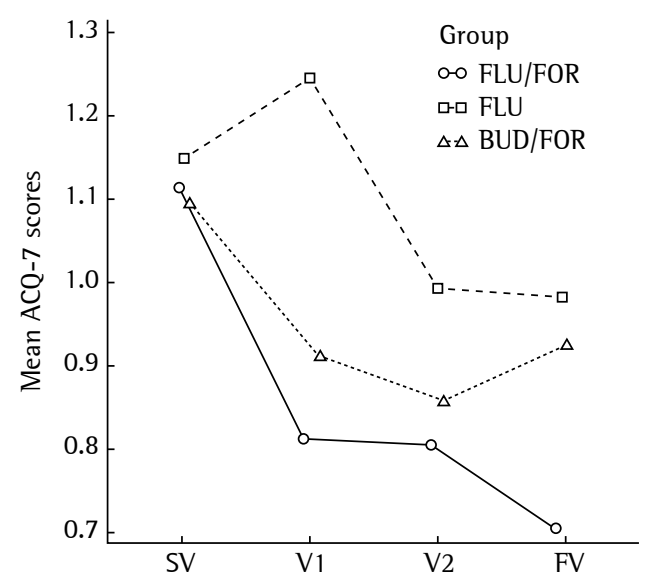

Figure 3 - Mean Asthma Control Questionnaire 7 (ACQ-7) scores in the fluticasone/formoterol (FLU/ FOR), fluticasone (FLU), and budesonide/formoterol (BUD/FOR) groups (intent-to-treat [ITT] population) at each visit. SV: screening visit; V1: visit 1; V2: visit 2; and FV: final visit.

there was a gradual reduction in ACQ-7 scores throughout the study in all three groups, the reduction was more consistent in those receiving $1 C+L A B A$ combinations, being more significant in the FLU/FOR group.

Assessment of asthma control by the investigators shows that the proportions of patients with controlled asthma were similar at the beginning of the study and changed during the study. In the FLU/FOR, BUD/FOR, and FLU groups, the proportions of patients with controlled asthma at the beginning of the study were 59\%, 60\%, and 66\%, respectively, whereas the proportions of patients with controlled asthma at the end of the study were 83\%, 63\%, and $68 \%$, respectively, the difference tending to be significant $(p=0.08)$ in the FLU/FOR group.

Scores $>7$ ( $>90 \%$ of correct answers) at all visits showed that the patients knew how to use the inhalers properly, with no differences among the groups. The decimal preference scale used showed no differences among the groups, with values above 8 points (> 80\%). Table 2 shows patient adherence to treatment. In all groups, adherence to treatment varied widely between the beginning and end of the study. However, there were no differences among the groups regarding the measures of central tendency for treatment adherence.

In the FLU/FOR, BUD/FOR, and FLU groups, the most common non-serious adverse events were asthma attacks (in 13.92\%, 16.87\%, and $17.50 \%$, respectively), nasopharyngitis (in 13.92\%, $21.69 \%$, and $21.25 \%$, respectively), and rhinitis (15.19\%, 16.87\%, and 25.00\%, respectively).

In the safety population ( $\mathrm{n}=242)$, only 2 patients in the FLU/FOR group had serious adverse events: 1 had an asthma attack related to the study treatment; and 1 had drug poisoning unrelated to the study treatment.

Median serum cortisol levels at the end of the treatment were within the normal range, with no statistically significant differences among the FLU/FOR, BUD/FOR, and FLU groups (9.85 $\pm 6.46 \mu \mathrm{g} / \mathrm{dL}, 10.32 \pm 5.19 \mu \mathrm{g} / \mathrm{dL}$, and $9.35 \pm$ $4.69 \mu \mathrm{g} / \mathrm{dL}$, respectively). 
Table 2 - Adherence to treatment in the intent-to-treat population of patients, distributed by treatment group $(\mathrm{n}=235)$.

\begin{tabular}{lccc}
\hline \multicolumn{1}{c}{ Adherence } & \multicolumn{3}{c}{ Groups } \\
\cline { 2 - 4 } & Fluticasone/formoterol & Budesonide/formoterol & Fluticasone \\
\hline RV to V1 & $(\mathrm{n}=75)$ & $(\mathrm{n}=82)$ & $(\mathrm{n}=77)$ \\
Mean \pm SD & $97.6 \pm 12.9$ & $94.2 \pm 12.3$ & $87.7 \pm 18.0$ \\
Range & $50.0-142.8$ & $8.9-111.1$ & $10.8-106.5$ \\
Median (IR) & $98.2(93.4-100.0)$ & $97.0(90.6-100.0)$ & $93.7(82.2-100.0)$ \\
V1 to V2 & $(\mathrm{n}=72)$ & $(\mathrm{n}=78)$ & $(\mathrm{n}=66)$ \\
Mean \pm SD & $98.1 \pm 7.4$ & $95.0 \pm 7.45$ & $95.0 \pm 7.4$ \\
Range & $66.6-121.1$ & $62.5-111.1$ & $66.3-110.0$ \\
Median (IR) & $98.2(95.8-100.0)$ & $96.7(90.9-100.0)$ & $96.4(91.8-100.0)$ \\
V2 to FV & $(\mathrm{n}=72)$ & $(\mathrm{n}=73)$ & $(\mathrm{n}=62)$ \\
Mean \pm SD & $97.5 \pm 5.9$ & $96.8 \pm 7.2$ & $92.7 \pm 11.4$ \\
Range & $75.3-108.5$ & $72.2-127.6$ & $42.8-107.2$ \\
Median (IR) & $99.4(96.0-100.0)$ & $98.2(94.6-100.0)$ & $96.35(88.5-100.0)$ \\
\hline
\end{tabular}

RV: randomization visit; IR: interquartile range; and FV: final visit.

\section{Discussion}

The present study compared the efficacy and safety of a single-capsule combination of fluticasone/formoterol $(250 \mu \mathrm{g} / 12 \mu \mathrm{g}$, delivered via a DPI) with those of budesonide/formoterol $(400 \mu \mathrm{g} / 12 \mu \mathrm{g}$, delivered via a DPI with two separate capsules) and fluticasone alone (500 $\mu \mathrm{g}$, delivered via a multiple-dose DPI) in patients with mild to moderate asthma. The primary efficacy analysis $\left(\mathrm{FEV}_{1}\right)$ showed that the new, singlecapsule combination of fluticasone/formoterol is non-inferior to the budesonide/formoterol combination or fluticasone alone. In addition, asthma control was shown to be similar among the groups, being slightly better in the FLU/ FOR group at the end of the study. The PEF at the end of the study was found to be higher in the groups of patients receiving formoterol. Patient adherence, preference, and acceptance were similar among the groups studied, as were adverse events.

Although the non-inferiority of the fluticasone/ formoterol combination was demonstrated in the present study, its superiority was not. The efficacy, safety, and tolerability of the fluticasone/ formoterol combination were evaluated in a study with a design similar to ours; however, in that study, the drugs were delivered via pressurized metered dose inhalers (MDls). ${ }^{(22)}$ The combination of fluticasone/formoterol delivered via a single pressurized $\mathrm{MDl}$, the fluticasone/formoterol combination delivered via two separate MDls, and fluticasone alone were also found to be non-inferior to one another in terms of FEV 1 values and safety outcomes. Post hoc analyses of the two studies showed significant differences in symptoms, asthma control, and PEF between the single-capsule combination of fluticasone/ formoterol delivered via a DPI and the fluticasone/ formoterol combination delivered via a single pressurized MDl, especially in comparison with fluticasone alone. Studies involving a larger number of patients might show these differences more clearly.

It has been demonstrated that fluticasone/ formoterol delivered via a single MDI is non-inferior to fluticasone/salmeterol delivered via a multipledose inhaler. ${ }^{(23)}$ However, the response to treatment was faster in the group of patients receiving formoterol, with a possible impact on patient preference and adherence. In the present study, two groups of patients received formoterol, and it was therefore impossible to distinguish clearly between the two. Patient preference for, acceptability of, and mean/median adherence to the different devices were similar in the present study. However, as can be seen in Table 2, the lowest adherence rates at the end of the study in the FLU/FOR and BUD/FOR groups were superior to those in the group of patients receiving an $1 \mathrm{C}$ alone.

Two meta-analyses ${ }^{(24,25)}$ and one systematic review $^{(17)}$ showed that the use of fluticasone is associated with better outcomes than is the use of budesonide. Despite the small number of comparative studies at the time, fluticasone was associated with better prevention of asthma 
exacerbations. ${ }^{(17)}$ Another difference observed is the need for higher doses of budesonide in order to achieve similar asthma control, probably because the fluticasone molecule has a higher binding affinity to the corticosteroid receptor and because of their different pharmacokinetic characteristics. $^{(26)}$

The efficacy of any inhaled asthma therapy in clinical practice depends on a number of factors, including the efficacy of the drug, the amount of drug released, correct inhaler use, the inhalation technique, and adherence to treatment. Poor adherence to maintenance treatment and the lack of asthma control in nearly $50 \%$ of the studies (including research protocols) appear to be associated with the aforementioned factors. More than 100 inhaler/drug combinations were available 5 years ago. ${ }^{(27)}$ Since then, the number of new drugs and inhalers has increased, and hydrofluoroalkane has emerged. The criteria for selecting the best inhaler vary among manufacturers, patients, and physicians. ${ }^{(28)}$ In the real world, clinical efficacy, local availability of the device, the price of the device, and patient preference/acceptance should be taken into consideration. Our decision to use a single-capsule combination of fluticasone/ formoterol delivered twice daily via a DPI appears to have contributed to treatment adherence. DPls are easier to use than are MDls. ${ }^{(29)}$

The inhaler used in the present study in order to deliver the new, single-capsule combination of fluticasone/formoterol (i.e., the CDM-Haler inhaler) was tested in vitro against the Diskus inhaler in order to determine the PEFs generated at $4 \mathrm{kPa}$ at constant volume, as well as dose uniformity and aerodynamic particle size distribution. The results showed dose uniformity and uniform aerodynamic particle size distribution at the beginning, middle, and end of 360 actuations in 10 of the inhalers tested. ${ }^{(30)}$

The strength of the present study is its design, which is consistent with other, similar, multicenter non-inferiority studies. The methodology allowed us to use ITT analysis and PP analysis to assess the study population and the primary outcome, respectively. However, the study might have been more robust if we had included only patients with severe uncontrolled asthma. The decision to exclude such patients was deliberate, given that the number of patients required in order to achieve non-inferiority would have been much larger, with a screening failure higher than the observed rate of 15\%. The use of asthma control measures by the patients and investigators, as well as objective assessments of treatment adherence and inhaler use, would have allowed us to detect signs of efficacy in part of the study population, allowing inferences about the personalization of asthma treatment.

National studies of new drugs (phase 111 studies) are important in order to analyze specific responses in the study population. Regulatory agencies in countries such as Japan and China do not allow the marketing of new drugs until national studies have been conducted, given that individual response to treatment varies across patient populations. In Brazil, there have been few multicenter studies in the respiratory field involving a large number of patients. The results of the present study show the importance of such studies, especially when they are aimed at providing drugs whose formulation might improve patient acceptance, preference, and adherence.

In conclusion, the present study demonstrated that the new, single-capsule combination of fluticasone/formoterol is non-inferior to reference drugs budesonide/formoterol and fluticasone. In addition, the fluticasone/formoterol combination showed comparable efficacy and safety, being able to control persistent asthma, as determined by objective assessment of the use of and adherence to inhaled asthma therapy. The use of this $1 C+L A B A$ combination as sole maintenance therapy represents an effective treatment option for patients with persistent asthma, especially those with an inadequate response to $1 \mathrm{Cs}$ in isolation or other $1 \mathrm{C}+\mathrm{LABA}$ combinations.

\section{Acknowledgments}

This national multicenter study was made possible by the work and commitment of the entire CAINAS FF group, including Regina Maria Carvalho Pinto, Elisa Lombardi, Ângela Honda, Luciene Angelini, Juliana Soprani, Clóvis Eduardo Santos Galvão, Givaneide Lima, Adelmir Souza-Machado, Joanemile Figueiredo, Suzana Zelmanovitz, Patrícia Ristori Dias Soares, Sabrina Souza e Silva, Herberto Chong Neto, Anna Beatriz Naumes, and Simone Fernandes.

\section{References}

1. Global Initiative for Asthma. Global strategy for asthma management and prevention. Bethesda: National Institutes of Health, National Heart, Lung, and Blood Institute; 2011. 
2. Sociedade Brasileira de Pneumologia e Tisiologia. Diretrizes da Sociedade Brasileira de Pneumologia e Tisiologia para o Manejo da Asma - 2012. J Bras Pneumol. 2012;38(Suppl 1):S1-S46.

3. Pauwels RA, Löfdahl CG, Postma DS, Tattersfield AE, O'Byrne P, Barnes PJ, et al. Effect of inhaled formoterol and budesonide on exacerbations of asthma. Formoterol and Corticosteroids Establishing Therapy (FACET) International Study Group. N Engl J Med. 1997;337(20):1405-11. http://dx.doi.org/10.1056/NEJM199711133372001

4. Schatz M, Zeiger RS, Vollmer WM, Mosen D, Cook EF. Determinants of future long-term asthma control. J Allergy Clin Immunol. 2006;118(5):1048-53. http:// dx.doi.org/10.1016/j.jaci.2006.07.057

5. Juniper EF, Kline PA, Vanzieleghem MA, Ramsdale EH, O’Byrne PM, Hargreave FE. Effect of long-term treatment with an inhaled corticosteroid (budesonide) on airway hyperresponsiveness and clinical asthma in nonsteroid-dependent asthmatics. Am Rev Respir Dis. 1990;142(4):832-6. http://dx.doi.org/10.1164/ ajrccm/142.4.832

6. Adams NP, Jones PW. The dose-response characteristics of inhaled corticosteroids when used to treat asthma: an overview of Cochrane systematic reviews. Respir Med 2006;100(8):1297-306. http://dx.doi.org/10.1016/j. rmed.2006.04.015

7. Greening AP, Ind PW, Northfield M, Shaw G. Added salmeterol versus higher-dose corticosteroid in asthma patients with symptoms on existing inhaled corticosteroid. Allen \& Hanburys Limited UK Study Group. Lancet 1994;344(8917):219-24. http://dx.doi.org/10.1016/ S0140-6736(94)92996-3

8. Bateman ED, Boushey HA, Bousquet J, Busse WW, Clark TJ, Pauwels RA, et al. Can guideline-defined asthma control be achieved? The Gaining Optimal Asthma ControL study. Am J Respir Crit Care Med. 2004;170(8):836-44. http://dx.doi.org/10.1164/rccm.200401-0330C

9. Lalloo UG, Malolepszy J, Kozma D, Krofta K, Ankerst J, Johansen B, et al. Budesonide and formoterol in a single inhaler improves asthma control compared with increasing the dose of corticosteroid in adults with mild-to-moderate asthma. Chest. 2003;123(5):1480-7. http://dx.doi.org/10.1378/chest.123.5.1480

10. Stoloff SW, Stempel DA, Meyer J, Stanford RH, Carranza Rosenzweig JR. Improved refill persistence with fluticasone propionate and salmeterol in a single inhaler compared with other controller therapies. J Allergy Clin Immunol 2004;113(2):245-51. http://dx.doi.org/10.1016/j. jaci.2003.10.011

11. Hoskins G, McCowan C, Neville RG, Thomas GE, Smith B, Silverman S. Risk factors and costs associated with an asthma attack. Thorax. 2000;55(1):19-24. http:// dx.doi.org/10.1136/thorax.55.1.19

12. Hess DR. Metered-dose inhalers and dry powder inhalers in aerosol therapy. Respir Care. 2005;50(10):1376-83.

13. Allen SC, Ragab S. Ability to learn inhaler technique in relation to cognitive scores and tests of praxis in old age. Postgrad Med J. 2002;78(915):37-9. http://dx.doi. org/10.1136/pmj.78.915.37

14. Dolovich MB, Ahrens RC, Hess DR, Anderson P, Dhand R, Rau JL, et al. Device selection and outcomes of aerosol therapy: Evidence-based guidelines: American College of Chest Physicians/American College of Asthma, Allergy, and Immunology. Chest. 2005;127(1):335-71. http:// dx.doi.org/10.1378/chest.127.1.335
15. Lasserson TJ, Cates CJ, Ferrara G, Casali L. Combination fluticasone and salmeterol versus fixed dose combination budesonide and formoterol for chronic asthma in adults and children. Cochrane Database Syst Rev 2008;(3):CD004106.

16. Adams N, Lasserson TJ, Cates $\mathrm{CJ}$, Jones PW. Fluticasone versus beclomethasone or budesonide for chronic asthma in adults and children. Cochrane Database Syst Rev 2007;(4):CD002310.

17. Frois C, Wu EQ, Ray S, Colice GL. Inhaled corticosteroids or long-acting beta-agonists alone or in fixed-dose combinations in asthma treatment: a systematic review of fluticasone/budesonide and formoterol/salmeterol. Clin Ther 2009;31(12):2779-803. http://dx.doi.org/10.1016/j. clinthera.2009.12.021

18. Juniper EF, O’Byrne PM, Guyatt GH, Ferrie PJ, King DR. Development and validation of a questionnaire to measure asthma control. Eur Respir J. 1999;14(4):902-7. http://dx.doi.org/10.1034/j.1399-3003.1999.14d29.x

19. World Medical Association [homepage on the Internet]. Ferney-Voltaire, France: WMA [cited 2014 Jun 9]. WMA Declaration of Helsinki - Ethical Principles for Medical Research Involving Human Subjects. Available from: http://www.wma.net/en/30publications/10policies/b3/

20. Reddel HK, Taylor DR, Bateman ED, Boulet LP, Boushey HA, Busse WW, et al. An official American Thoracic Society/European Respiratory Society statement: asthma control and exacerbations: standardizing endpoints for clinical asthma trials and clinical practice. Am J Respir Crit Care Med. 2009;180(1):59-99. http://dx.doi. org/10.1164/rccm.200801-060ST

21. Quanjer PH, Lebowitz MD, Gregg I, Miller MR, Pedersen OF. Peak expiratory flow: conclusions and recommendations of a Working Party of the European Respiratory Society. Eur Respir J Suppl. 1997;24:2S-8S.

22. Bodzenta-Lukaszyk A, Pulka G, Dymek A, Bumbacea D, Mclver T, Schwab B, et al. Efficacy and safety of fluticasone and formoterol in a single pressurized metered dose inhaler. Respir Med. 2011;105(5):674-82 http:// dx.doi.org/10.1016/j.rmed.2010.11.011

23. Bodzenta-Lukaszyk A, Dymek A, McAulay K, Mansikka $\mathrm{H}$. Fluticasone/formoterol combination therapy is as effective as fluticasone/salmeterol in the treatment of asthma, but has a more rapid onset of action: an openlabel, randomized study. BMC Pulm Med. 2011;11:28. http://dx.doi.org/10.1186/1471-2466-11-28

24. Barnes NC, Thwaites RM, Price MJ. The cost-effectiveness of inhaled fluticasone propionate and budesonide in the treatment of asthma in adults and children. Respir Med. 1999;93(6):402-7. http://dx.doi.org/10.1053/ rmed.1999.0577

25. Stempel DA, Stanford RH, Thwaites R, Price MJ. Costefficacy comparison of inhaled fluticasone propionate and budesonide in the treatment of asthma. Clin Ther. 2000;22(12):1562-74. http://dx.doi.org/10.1016/ S0149-2918(00)83054-4

26. Derendorf H, Meltzer EO. Molecular and clinical pharmacology of intranasal corticosteroids: clinical and therapeutic implications. Allergy. 2008;63(10):1292-300. http://dx.doi.org/10.1111/j.1398-9995.2008.01750.x

27. Lavorini F, Corbetta L. Achieving asthma control: the key role of inhalers. Breathe. 2008;5(2):121-31.

28. Virchow JC. What plays a role in the choice of inhaler device for asthma therapy? Curr Med Res Opin. 2005;21 Suppl 4:S19-25. http://dx.doi.org/10.1185/030079905X61758 
29. Santos Dde 0, Martins MC, Cipriano SL, Pinto RM, Cukier A, Stelmach R. Pharmaceutical care for patients with persistent asthma: assessment of treatment compliance and use of inhaled medications. J Bras Pneumol. 2010;36(1):14-22.
30. Soares DL, Barros Silva W. Relatório do estudo de avaliação da uniformidade de dose liberada e distribuição aerodinâmica em diferentes taxas de fluxo. São Paulo: Eurofarma Laboratório SA. Área de Desenvolvimento de Novos Produtos. 2013 Apr.

\section{About the authors}

\section{Marti Antilla}

Allergist. Consultoria Médica em Pesquisa Clínica - CMPC, Medical Consulting Center for Clinical Research - Sorocaba, Brazil.

\section{Fábio Castro}

Tenured Professor of Allergology and Immunology, University of São Paulo School of Medicine, São Paulo, Brazil.

\section{Álvaro Cruz}

Associate Professor. Federal University of Bahia, Salvador, Brazil.

\section{Adalberto Rubin}

Adjunct Professor. Federal University of Health Sciences of Porto Alegre, Porto Alegre, Brazil.

\section{Nelson Rosário}

Full Professor. Federal University of Paraná, Curitiba, Brazil.

\section{Rafael Stelmach}

Tenured Professor. University of São Paulo School of Medicine, São Paulo, Brazil. 